\section{Accelerated aging methodologies for evaluating physiological potential of treated soybean seeds}

\author{
Rayssa Fernanda dos Santos ${ }^{1 *}$ (D), Henrique Fabrício Placido ${ }^{1}$ (D) , Leonardo \\ Lemes Bosche ${ }^{2}$ (D) Hugo Zeni Neto ${ }^{1}$ (D), Fernando Augusto Henning ${ }^{3}$ (D), \\ Alessandro Lucca Braccini ${ }^{1}$
}

ABSTRACT: This work evaluated the efficiency of accelerated aging test to determine the physiological potential in treated soybean seeds with fungicides and insecticides, in addition to analyzing the concordance between the results obtained by different accelerated aging methods with the actual results of the physiological quality in seeds after the storage. The study was divided into two experiments, both with entirely randomized delineation, with four replications. In the first experiment, seed germination was evaluated after imposing some treatments that were arranged in a $3 \times 2 \times 3$ factorial scheme: seed treatment (imidacloprid + thiodicarb; fipronil + thiophanate methyl + pyraclostrobin; no treatment); vigor levels (high; low); and accelerated aging (traditional; saturated $\mathrm{NaCl}$ solution; no aging). In the second experiment, seedling emergence was evaluated after applying some treatments that were arranged in a $3 \times 2 \times 2$ factorial scheme: seed treatment (imidacloprid + thiodicarb; fipronil + thiophanate methyl + pyraclostrobin; no treatment); vigor levels (high; low); storage time (0 and 135 days). The accelerated aging methods were efficient to determine the physiological potential of the seeds, in which, the $\mathrm{NaCl}$ method presented better results. The physiological potential of soybean seeds decreased throughout storage and the application of chemicals in seed treatment impaired the germination and emergence percentages, regardless of the active ingredient used. The accelerated aging method with $\mathrm{NaCl}$ presents greater agreement with the actual storage results.

Index terms: Glycine max, seed treatment, germination, vigor.

RESUMO: O objetivo deste estudo foi avaliar a eficiência do teste de envelhecimento acelerado para determinar o potencial fisiológico de sementes de soja com diferentes tratamentos químicos; verificar a influência do tratamento de sementes após o armazenamento e analisar a concordância entre os métodos de envelhecimento acelerado com os resultados reais de armazenamento das sementes. $O$ estudo foi dividido em dois experimentos, ambos com delineamento inteiramente casualizado, com quatro repetições. No primeiro experimento os tratamentos foram dispostos em esquema fatorial $3 \times 2 \times 3$ : três tratamento de sementes (imidacloprid + thiodicarb; fipronil + thiophanate methyl + pyraclostrobin; ausência de tratamento), dois níveis de vigor (alto; baixo) e três métodos de envelhecimento acelerado (tradicional; solução saturada de $\mathrm{NaCl}$; sem envelhecimento) avaliando-se a germinação. No segundo experimento, os tratamentos foram dispostos em esquema fatorial $3 \times 2 \times 2$ : três tratamentos de sementes (imidacloprid + thiodicarb; fipronil + thiophanate methyl + pyraclostrobin; ausência de tratamento), dois níveis de vigor (alto; baixo), dois tempos de armazenamento (0 e 135 dias), avaliando-se a germinação e emergência de plântulas. Os métodos de envelhecimento acelerado foram eficientes para determinar o potencial fisiológico das sementes, em que, o $\mathrm{NaCl}$ apresentou melhores resultados. O potencial fisiológico das sementes de soja reduziu ao longo do armazenamento e a aplicação de produtos químicos no tratamento de sementes prejudicou as porcentagens de germinação e emergência, independente do ingrediente ativo utilizado. O método de envelhecimento acelerado com $\mathrm{NaCl}$ apresenta maior concordância com os resultados reais de armazenamento.

Termos para indexação: Glycine max, tratamento de sementes, germinação, vigor.
Journal of Seed Science, v.43, e202143028, 2021

http://dx.doi.org/10.1590/ 2317-1545v43250605

\section{*Corresponding author} E-mail: rayssaagro@gmail.com

Received: 04/01/2021

Accepted: 09/07/2021

\footnotetext{
${ }^{1}$ Programa de Pós-graduação em Agronomia, Universidade Estadual de Maringá, 87020-900, Zona 7, Maringá, Paraná, Brasil.
}

${ }^{2}$ Departamento de Agronomia, Universidade Estadual de Maringá, 87020-900, Zona 7, Maringá, Paraná, Brasil

${ }^{3}$ Empresa Brasileira de Pesquisa Agropecuária, Embrapa Soja, Tecnologia de Sementes, 860001970, Distrito de Warta, Paraná, Brasil. 


\section{INTRODUCTION}

Soybean currently occupies about $59 \%$ of the cultivated area for grain production in Brazil, placing the country among the world's largest grain producers (CONAB, 2020). The achievement of high crop yield is based on the adoption of several technologies and the use of seeds with high physiological potential is essential for an adequate plant establishment in the field.

The evaluation of the physiological potential allows to sort seed lots regarding germination and vigor, enabling to estimate the physiological performance of the seeds in the field or over storage (Marcos-Filho, 2015).

Several physiological tests have been recommended for assessing the vigor of soybean seeds, including the accelerated aging, which had been internationally recognized for years as the most widely used to assess the physiological potential of various legume species, providing information with a high degree of consistency (Tekrony, 2003). This test has as principle the increase of the deterioration rate by the exposure of the seeds to high levels of temperature and relative air humidity, both considered preponderant environmental factors that impact on the intensity and speed of deterioration (Delouche, 2002), simulating inadequate conditions of storage (Marcos-Filho, 2015).

Although numerous studies on the accelerated aging test have been conducted to assess the physiological potential of soybean seeds, only few have focused on a assessing the efficiency of accelerated aging methods for chemically treated soybean seeds. Seed treatment with fungicides and insecticides is responsible for providing additional protection to the seeds, assuring good performance even in adverse climate and soil conditions (Henning, 2005).

Seed treatment is usually carried out at pre-sowing, on the property or at resellers; however, with the advancement of technology, the use of industrial treatment performed by the seed producers has grown considerably, in which the seeds are treated in the processing plant and, then, stored in controlled conditions until sowing (Abati et al., 2013).

This work evaluated the efficiency of accelerated aging test to determine the physiological potential in treated soybean seeds with fungicides and insecticides, in addition to analyzing the concordance between the results obtained by different accelerated aging methods with the actual results of the physiological quality in seeds after the storage.

\section{MATERIAL AND METHODS}

The research was carried out at the Seed Analysis Laboratory of Maringá State University (UEM), in Maringá, Paraná, Brazil. Two soybean seed lots from the cultivar TMG 7062 IPRO were used, one of high and the other (86\%) of low vigor (74\%), according to the tetrazolium test described by França-Neto et al. (2018). The seeds were treated with some active ingredients (Table 1 ).

For both seed treatments, polymer (Peridiam ${ }^{\circledR}$ ) and drying powder (Talkum gloss ${ }^{\circledR}$ ) were added. The chemical treatment of the seeds was carried out in plastic bags in which the products were added over the seeds, followed by shaking until the seeds were completely covered, with volume of the mixture of $600 \mathrm{~mL} .100 \mathrm{~kg}^{-1}$ of seeds.

After treatment, the study was divided into two experiments. The first aimed at checking the efficiency of accelerated aging testing to determine the physiological potential of treated soybean seeds, while the second aimed to understand if the influence of the chemical treatment varies depending on seed vigor level and storage time.

Table 1. Active ingredients and doses used for chemical treatment of seeds.

\begin{tabular}{lcc}
\hline \multicolumn{1}{c}{ Active ingredients } & Type $^{1}$ & Commercial Dose $^{2}$ \\
\hline imidacloprid + thiodicarb & $\mathrm{I}+\mathrm{I}$ & 300 \\
fipronil + thiophanate methyl + pyraclostrobin & $\mathrm{I}+\mathrm{F}+\mathrm{F}$ & 200 \\
Control & - & - \\
\hline
\end{tabular}

${ }^{1}$ Type: I: insecticide; F: fungicide. ${ }^{2}$ Commercial product dose: $\mathrm{mL} .100 \mathrm{~kg}^{-1}$ of seeds. 


\section{Experiment I:}

The experiment was carried out using a completely randomized design, with four replications. The treatments were arranged in a factorial scheme $3 \times 2 \times 3(A \times B \times C)$ : in which factor $A$ was composed by the application of seed treatment with insecticides and fungicides [imidacloprid + thiodicarb; fipronil + thiophanate methyl + pyraclostrobin; control (no treatment)], factor B for vigor levels (high; low) as determined by the tetrazolium test, and factor $\mathrm{C}$ for accelerated aging methods (traditional; saturated $\mathrm{NaCl}$ solution; no aging).

Initially, the moisture content of the seeds was determined by the oven method at $105^{\circ} \mathrm{C}\left( \pm 3{ }^{\circ} \mathrm{C}\right)$, for 24 hours, as described in the Brazilian Rules for Seed Testing (Brasil, 2009). This determination was also made after the period of exposure of the seeds to the accelerated aging process.

Treated and untreated (control) seeds were both submitted to:

i) traditional accelerated aging test as described in Marcos-Filho (2020) at $41^{\circ} \mathrm{C}$, for 48 hours as well as accelerated aging over saturated $\mathrm{NaCl}$ solution at $41{ }^{\circ} \mathrm{C}$, for 48 hours (Marcos-Filho et al., 2000). Subsequently, the germination test was carried out with four subsamples of 50 seeds for each lot (Brasil, 2009). The results were expressed as average percentages of normal seedlings.

The data obtained were submitted to the analysis of the basic assumptions of the analysis of variance by the Lilliefors tests $(p \leq 0.05)$ and Bartlett's sphericity tests $(p<0.05)$. All factors were considered fixed. Then, the data were subjected to analysis of variance and the means compared by the Tukey test $(p \leq 0.05)$.

\section{Experiment II:}

The experiment was carried out using a completely randomized design, with four replications, in which the treatments were arranged in a factorial scheme $3 \times 2 \times 2(A \times B \times C)$ : factor $A$ was composed by the seed treatment with insecticides and fungicides [imidacloprid + thiodicarb; fipronil + thiophanate methyl + pyraclostrobin; control (no treatment)], while the factor $\mathrm{B}$ was considered the vigor levels (high; low) as determined by the tetrazolium test, and factor $C$ the storage times ( 0 and 135 days).

Seeds of both vigor levels were stored in paper bags, in a laboratory environment, under uncontrolled conditions of temperature and relative humidity for the periods previously mentioned (the average temperature was $25^{\circ} \mathrm{C} \pm 4{ }^{\circ} \mathrm{C}$ and relative humidity was $60 \% \pm 14 \%$ within the period).

Then, the physiological potential of the seeds was evaluated by the germination test, as previously described (Brasil, 2009) and seedling emergence in sand substrate, in a greenhouse under controlled irrigation (water quantity corresponding to $60 \%$ of the substrate retention capacity), with four replications of 50 seeds for each lot, evaluation was performed at 14 days after sowing (Brasil, 2009).

The data were submitted to the analysis of the basic assumptions of the analysis of variance by the Lilliefors tests $(p \leq 0.05)$ and Bartlett's sphericity tests $(p<0.05)$. All factors were considered fixed. Then, the data were subjected to analysis of variance and the means compared by the Tukey test $(p \leq 0.05)$.

To verify the hypothesis of agreement between the accelerated aging methods and the real results of seed storage, the results of the first experiment were compared with the second one by the chi-square adherence test $(p \leq 0.10)$. The statistical analysis was carried out by the software $\mathrm{R}^{\circledR}$ version 3.6.3 and the data package "ExpDes.pt" was used ( $\mathrm{R}$ Core Team, 2018; Ferreira et al., 2014).

\section{RESULTS AND DISCUSSION}

The data from both experiments met the basic assumptions of the analysis of variance $(p \leq 0.05)$. Through the analysis of variance, it is possible to infer those significant differences occurred $(p \leq 0.05)$ for all the response variables evaluated in experiment I and II, according to Tables 2 and 3. 
Table 2. Summary of variance analysis of the germination of treated soybean seeds obtained in the Experiment I.

\begin{tabular}{lc}
\hline \multicolumn{1}{c}{ SV } & Mean Square \\
\hline Active ingredients & $325.06^{*}$ \\
Vigor & $3556.06^{*}$ \\
Accelerated aging & $6766.72^{*}$ \\
Active ingredients *Vigor & $2.06^{\text {ns }}$ \\
Active ingredients * Accelerated aging & $83.22^{\text {ns }}$ \\
Vigor* Accelerated aging & $393.72^{*}$ \\
Active ingredients*Vigor* Accelerated aging & $90.72^{\text {ns }}$ \\
Residue & 39.8 \\
\hline & C.V.(\%) \\
\hline
\end{tabular}

*Significant at $5 \%$ probability level by the F test; ns: not significant; SV: Source of variation. C.V.: Coefficient of variation.

Table 3. Summary of variance analysis of germination, referring to experiment II, in soybean seeds treated for the variables germination and emergence.

\begin{tabular}{|c|c|c|}
\hline \multirow{2}{*}{ SV } & \multicolumn{2}{|c|}{ Mean Square } \\
\hline & Germination & Emergence \\
\hline Active ingredients & $300.06^{*}$ & $727.00^{*}$ \\
\hline Storage & $3056.02^{*}$ & $290.08^{*}$ \\
\hline Vigor & $295.02^{*}$ & $1408.33^{*}$ \\
\hline Active ingredients * Storage & $134.4^{\text {ns }}$ & $39.58^{\text {ns }}$ \\
\hline Active ingredients *Vigor & $187.15^{*}$ & $80.33^{*}$ \\
\hline Storage *Vigor & $6.02^{\text {ns }}$ & $36.75^{\mathrm{ns}}$ \\
\hline Active ingredients $*$ Storage *Vigor & $109.15^{\mathrm{ns}}$ & $47.25^{\mathrm{ns}}$ \\
\hline Residue & 48.19 & 22.26 \\
\hline C.V. (\%) & 3.97 & 2.07 \\
\hline
\end{tabular}

*Significant at $5 \%$ probability level by the $\mathrm{F}$ test; $\mathrm{ns}$ : not significant; SV: Source of variation. C.V.: Coefficient of variation.

Considering the germination results obtained in experiment I, there was no significant interaction among the factors: seed treatment, vigor levels and accelerated aging. However, there was a significant effect between the factors accelerated aging and vigor, indicating the dependence of these factors (Table 2).

Regarding the germination results obtained in experiment II, there was no significant interaction between the factors seed treatment, vigor levels and storage time. It was observed a significant effect only between the factors seed treatment and levels of vigor (Table 3).

For seedling emergence, there was no significant interaction among the factors: seed treatment, vigor levels and seed storage. A significant effect was observed between the seed treatment and vigor factors (Table 3).

\section{Experiment I}

The data distribution pattern could be best observed by exploratory data analysis, using the Boxplot chart (Figure 1).

It was observed that seeds submitted of accelerated aging had their potential of commercialization compromised, since the average of normal seedlings in the germination test was below $80 \%$ (Table 4), a minimum standard for soybean seed commercialization in Brazil, as established by the Ministry of Agriculture, Livestock and Food Supply (Brasil, 2013). 


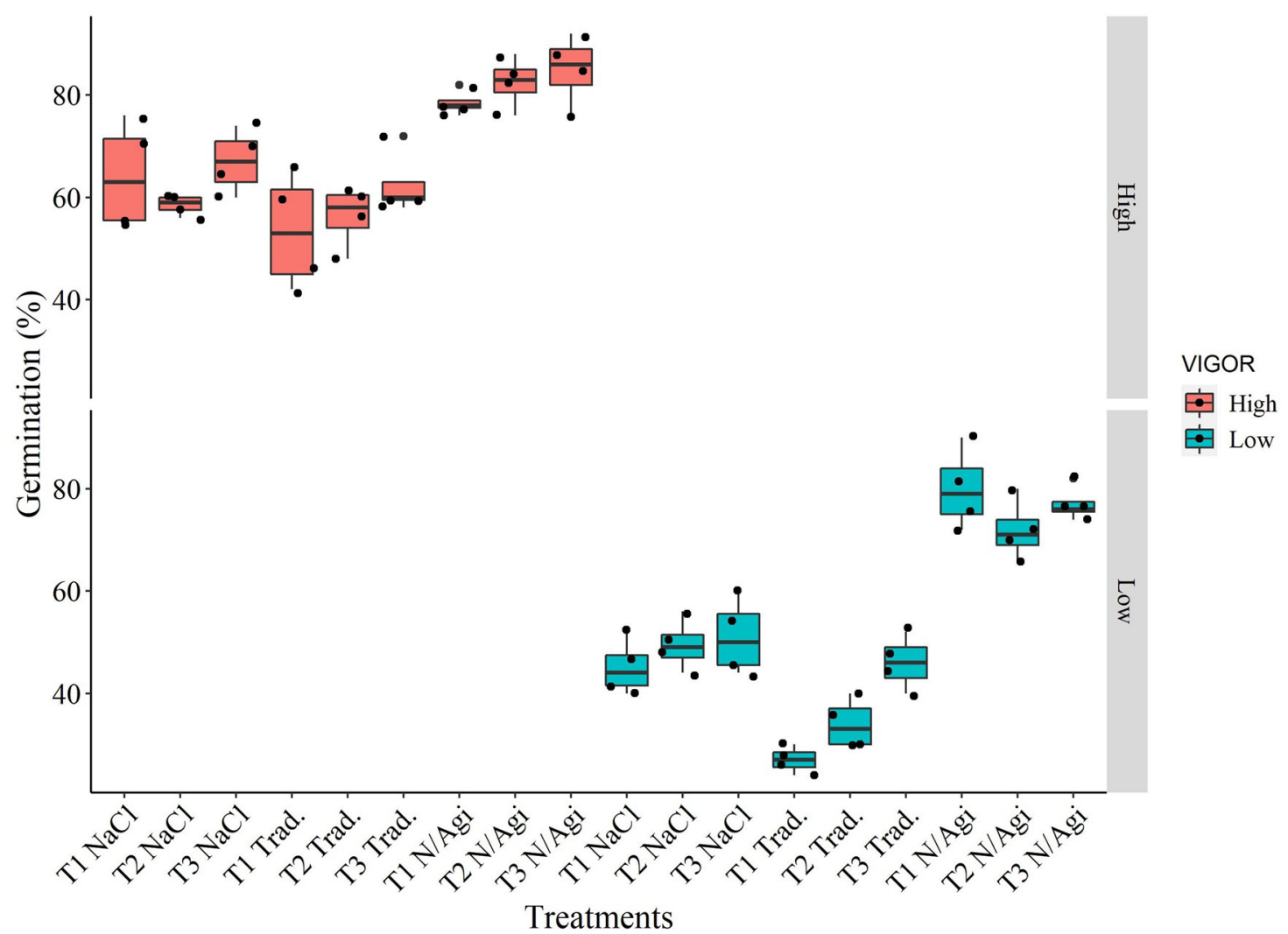

Figure 1. Exploratory data analysis for experiment I using Boxplot. T1: imidacloprid+thiodicarb; T2: fipronil+thiophanate methyl+pyraclostrobin; T3: control; $\mathrm{NaCl}$ : accelerated aging with saturated $\mathrm{NaCl}$ solution; Trad: accelerated aging traditional; N/Agi: no aging.

Table 4. Germination (\%) of soybean seeds with two vigor levels, as determined by the tetrazolium test, after exposure to different accelerated aging procedures.

\begin{tabular}{ccc}
\hline Accelerated aging & \multicolumn{3}{c}{ Germination (\%) } \\
\cline { 2 - 3 } & \multicolumn{3}{c}{ Seed Vigor Level } \\
\hline Method & High & $36 \mathrm{Cb}$ \\
Traditional & $57 \mathrm{Ba}$ & $48 \mathrm{Bb}$ \\
Saturated NaCl solution & $63 \mathrm{Ba}$ & $76 \mathrm{Ab}$ \\
No aging & $82 \mathrm{Aa}$ & La \\
\hline
\end{tabular}

* Means followed by the same capital letters in the column and lower case in the line do not differ from each other by Tukey's test ( $p \leq 0.05$ ).

Analyzing the data, as expected, higher germination values were observed in the high-vigor level lot, regardless of the accelerated aging test used (Table 4). These results are justified, as seeds of high initial vigor perform better under wide variation of environmental conditions (Marcos-Filho, 2015).

Within the high vigor level, we observed that unaged seeds showed the best results and the aging methods do not differ from each other (Table 4). The reduction of germination with accelerated aging procedure is related to the principles of the test, which simulate a stressful situation with high temperature and high relative humidity (Delouche, 2002).

Seeds with low initial vigor, the highest vigor percentages were found in unaged seeds, followed by seeds aged with saturated $\mathrm{NaCl}$ solution and by the traditional method. This trend occurs because the use of $\mathrm{NaCl}$ provides a relative 
humidity of $76 \%$, lower than the traditional test (close to $100 \%$ ), thus, reducing the absorption of water by the seeds and, consequently, the intensity of deterioration of the seeds (Marcos-Filho et al., 2000).

The moisture content of the seeds at the beginning of the evaluations ranged from 9.0 to $9.2 \%$, while after the traditional accelerated aging test the moisture content was from 24.0 to $25.0 \%$ and for seeds aged with saturated solution 12.0 to $13.1 \%$. Thus, the moisture content of seeds aged with saturated $\mathrm{NaCl}$ solution is closer to reality during the storage of seeds of most cultivated species (Marcos-Filho, 2015).

In addition, a significant effect was found evaluating the active ingredient factor alone. Generally, treatments with the chemical products application showed reductions in seedling germination (Table 5). This reduction may be associated with possible phytotoxicity caused by the action of the active ingredients on the development of the seedlings (Ludwig et al., 2011).

Some works with seeds from different species, evidence that the application of fungicides and insecticides can be adverse to seeds physiological potential even a few hours after the application of the treatment. Among them, there can be highlighted the researches carried out by Dan et al. (2011) and Henning (2006) in soybean, Lorenzetti et al. (2014) in corn and Vecchiato et al. (1994) in beans.

However, this reduction in physiological potential can present different levels depending on the cultivar, some of which may be more sensitive to the active ingredients action, as highlighted by França-Neto et al. (2000). In addition, for a better understanding of this deleterious physiological action of these pesticides on the seeds and seedlings, further studies are needed, which was not the focus of this research.

\section{Experiment II}

For seed treatments, in which the active ingredients were applied, there was no significant difference between high and low vigor seeds, except for the control (without treatment), in which, the high vigor level showed better results (Table 6).

For the seed vigor factor, higher germination values were observed for untreated seeds with a high initial vigor level, whereas for seeds with low vigor there was no significant difference between treatments (Table 6).

Table 5. Germination (\%) of soybean seeds treated with insecticides and fungicides.

\begin{tabular}{lc}
\hline \multicolumn{1}{c}{ Active ingredients } & Germination (\%) \\
\hline imidacloprid + thiodicarb & $58 \mathrm{~B}$ \\
fipronil + thiophanate methyl + pyraclostrobin & $59 \mathrm{~B}$ \\
Control & $65 \mathrm{~A}$ \\
\hline
\end{tabular}

* Means followed by the same capital letters in the column do not differ from each other by Tukey's test $(p \leq 0.05)$.

Table 6. Germination (\%) of treated soybean seeds of different vigor levels.

\begin{tabular}{lll}
\hline & \multicolumn{2}{c}{ Germination (\%) } \\
\cline { 2 - 3 } \multicolumn{1}{c}{ Active ingredients } & High & Seed Vigor Level \\
\cline { 2 - 3 } & $68 \mathrm{Ba}$ & $70 \mathrm{Aa}$ \\
\hline imidacloprid + thiodicarb & $71 \mathrm{Ba}$ & $67 \mathrm{Aa}$ \\
fipronil + thiophanate methyl + pyraclostrobin & $82 \mathrm{Aa}$ & $70 \mathrm{Ab}$ \\
Control & & \multicolumn{2}{c}{ La } \\
\hline
\end{tabular}

*Means followed by the same capital letters in the column and lower case in the line do not differ from each other by Tukey's test ( $\mathrm{s} \leq 0.05)$. 
Possibly, this difference in germination between seeds with and without the application of chemical treatment may be associated with the active ingredients present in seed treatment, which may reduce seed germination (Munkvold et al., 2006).

Despite their protective function, some fungicides and insecticides have characteristics capable of modifying the plant's metabolism and, consequently, altering its initial growth and development (Castro et al., 2009).

Similar results were found by Dan et al. (2012), Pereira et al. (2011) and Abati et al. (2020), with application of chemicals, reduced the seed physiological potential.

When evaluating the storage period factor alone, there was a significant effect, in which the storage period of 135 days proved to be harmful for seed germination (Table 7).

Numerous studies indicate that treated soybean seeds show a reduction in their physiological potential during storage (Dan et al., 2011; Pereira et al., 2018; Abati et al., 2020), either due to uncontrolled storage conditions, due to genetic factors or to the post-harvest management (Baudet and Villela, 2012).

The analysis of seedling emergence data indicates that the use of imidacloprid + thiodicarb or fipronil + thiophanate methyl + pyraclostrobin in seed treatment can reduce the emergence, especially in low vigor seeds (Table 8).

Considering the active ingredients, it was found that high vigor seeds showed better results of seedling emergence, regardless of the seed treatment used. These results corroborate with Marcos-Filho (2015), who points out that seeds with high quality have less fluctuation in the percentage of emerged seedlings.

Better seedling emergence results for non-treated seeds were observed, indicating again that the application of imidacloprid + thiodicarb or fipronil + thiophanate methyl + pyraclostrobin can reduce the values of seedling emergence in sand (Table 8).

Regarding the storage period factor in isolation, there was a significant effect, in which the storage period of 135 days presented the lowest values of seedling emergence (Table 9).

The percentage of seedling emergence reduced with storage, which may be associated with the natural process of seed deterioration (Table 9). According to Marcos-Filho (2015), the deterioration of seeds provides reduction in germination and seedling emergence, however, it is possible to decrease their speed of deterioration, storing the seeds in controlled conditions of humidity and temperature.

Table 7. Means obtained in the germination (\%) of soybean seeds treated for the storage period factor.

\begin{tabular}{cc}
\hline Storage period (days) & Germination (\%) \\
\hline 0 & $79 \mathrm{~A}$ \\
135 & $63 \mathrm{~B}$ \\
\hline
\end{tabular}

*Means followed by the same capital letters in the column do not differ from each other by Tukey's test $(p \leq 0.05)$.

Table 8. Means obtained in the seedling emergence (\%) of soybean seeds treated for the active ingredient and vigor factors.

\begin{tabular}{lcc}
\hline & \multicolumn{2}{c}{ Emergence (\%) } \\
\cline { 2 - 3 } \multicolumn{1}{c}{ Active ingredients } & \multicolumn{2}{c}{ Seed Vigor Level } \\
\cline { 2 - 3 } & $84 \mathrm{Ba}$ & Low \\
\hline imidacloprid + thiodicarb & $89 \mathrm{Ba}$ & $75 \mathrm{Bb}$ \\
fipronil + thiophanate methyl + pyraclostrobin & $96 \mathrm{Aa}$ & $73 \mathrm{Bb}$ \\
control & $88 \mathrm{Ab}$ \\
\hline *Mean follow
\end{tabular}

*Means followed by the same capital letters in the column and lower case in the line do not differ from each other by Tukey's test ( $p \leq 0.05)$. 
Table 9. Seedling emergence (\%) of treated soybean seeds over a period of 135 days of storage.

\begin{tabular}{cc}
\hline Storage period (days) & Emergence (\%) \\
\hline 0 & $86 \mathrm{~A}$ \\
135 & $81 \mathrm{~B}$ \\
\hline
\end{tabular}

*Means followed by the same capital letters in the column do not differ from each other by Tukey's test $(p \leq 0.05)$.

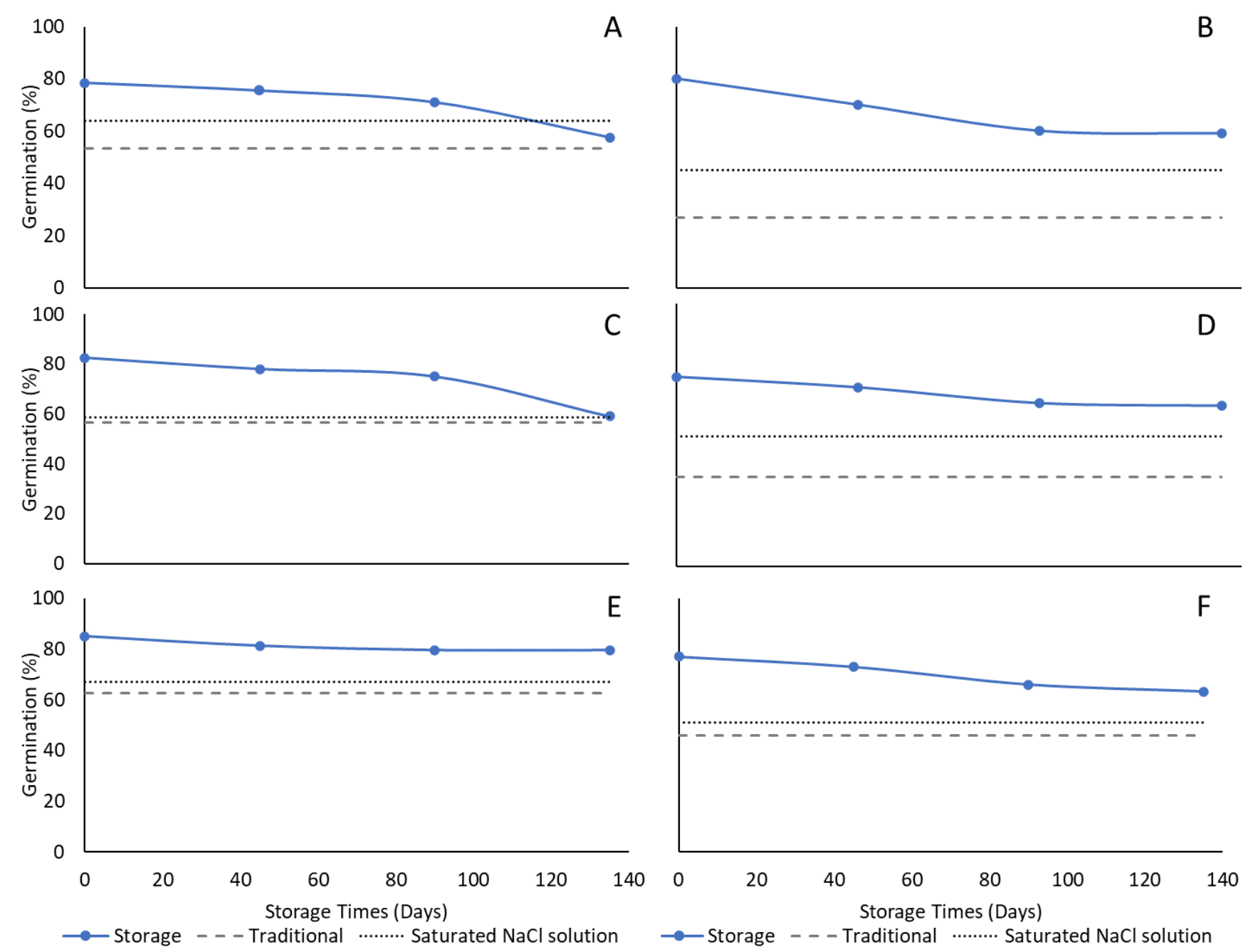

Figure 2. Agreement between accelerated aging methods with actual results of seed germination after a period of storage. A) imidacloprid + thiodicarb for high initial vigor seeds; B) imidacloprid + thiodicarb for low initial vigor seeds; C) fipronil + thiophanate methyl + pyraclostrobin for high initial vigor seeds; D) fipronil + thiophanate methyl + pyraclostrobin for low initial vigor seeds; E) Control for high initial vigor seeds; F) Control for low initial vigor seeds.

The Chi-square test was used to verify the probability distributions of the variables traditional accelerated aging and accelerated aging with saturated $\mathrm{NaCl}$ solution, in relation to the germination percentage of seeds stored for 135 days (theoretically expected values); having as a null hypothesis the adherence of the data (Assis et al., 2020).

It was observed that only the accelerated aging with saturated $\mathrm{NaCl}$ solution has no significant effect compared with the theoretically expected values, indicating that this method is the one that most resembles the 135-day storage period (Figure 2). 
These results can be seen in Figure 2, in which the accelerated aging with saturated $\mathrm{NaCl}$ solution, evaluated in experiment I (Table 4), presents germination results very similar to the actual values during storage (Table 7), evidencing that the accelerated aging test with saturated $\mathrm{NaCl}$ solution is the most suitable to estimate the seed storage potential, especially for seeds with low initial vigor.

These results corroborate Marcos-Filho (2015), who states that accelerated aging with saturated $\mathrm{NaCl}$ solution is more convenient than the traditional method for assessing the seed storage potential between harvest and sowing.

\section{CONCLUSIONS}

Both methods of the accelerated aging were efficient to determine the physiological potential of soybean seeds.

The physiological potential of soybean seeds reduces during the storage period, being enhanced by the use of the products and doses tested.

There was an agreement between the aging methods tested and the actual results of the physiological potential after storage, in which accelerated aging with $\mathrm{NaCl}$ was closer to the actual results.

\section{ACKNOWLEDGMENTS}

This work was carried out with the support of the Coordination for the Improvement of Higher Education Personnel - Brazil (CAPES) - Financing Code 001, and the "Brazilian Agricultural Research Corporation - Embrapa Soybean", Londrina - Brazil.

\section{REFERENCES}

ABATI, J.; BREZEZINSKI, C.R.; HENNING, A.A. Importância do tratamento de sementes de soja. Revista Cultivar, v.13, n.41, p.30-32, 2013.

ABATI, J.; BRZEZINSKI, C.R.; BERTUZZI, E.C.; HENNING, F.A.; ZUCARELI, C. Physiological response of soybean seeds to spray volumes of industrial chemical treatment and storage in different environments. Journal of Seed Science, v.42, e202042002, 2020. https:// doi.org/10.1590/2317-1545v42221062

ASSIS, J.P.; SOUSA, R.P.; LINHARES, P.C.F. Testes de hipóteses estatísticas. Mossoró: EdUFERSA, 2020. 183 p.

BAUDET, L.M.; VILLELA, F.A. Armazenamento de sementes. In: PESKE, S.T.; VILLELA, F.A.; MENEGHELLO, G.E. (Ed.) Sementes: fundamentos científicos e tecnológicos. Universitária, 2012. p.481-528.

BRASIL. Ministério da Agricultura, Pecuária e Abastecimento. Regras para análise de sementes. Ministério da Agricultura, Pecuária e Abastecimento. Secretaria de Defesa Agropecuária. Brasília: MAPA/ACS, 2009. 399p. https://www.gov.br/agricultura/pt-br/ assuntos/insumos-agropecuarios/arquivos-publicacoes-insumos/2946_regras_analise_sementes.pdf

BRASIL. Instrução normativa no 45, de 17 de setembro de 2013 - Instrução normativa No 45, de 17 de setembro de 2013 - DOU Imprensa Nacional. 2013. https://www.in.gov.br/en/web/dou/-/instrucao-normativa-n-45-de-17-de-setembro-de-2013-31057073.

CASTRO, P.R.C.; SERCILOTO, C.; PEREIRA, M.A.; RODRIGUES, J.L.M.; ROSSI, G. Agroquímicos de controle hormonal, fosfitos e potencial de aplicação dos aminoácidos na agricultura tropical. Piracicaba: Série Produtor Rural, 2009. 83 p.

CONAB. Conab - Safra Brasileira de Grãos. 2020. https://www.conab.gov.br/info-agro/safras/graos.

DAN, L.G.M.; DAN, H.A.; PICCININ, G.G.; RICCI, T.T.; ORTIZ, A.H.T. Tratamento de sementes com inseticida e a qualidade fisiológica de sementes de soja. Revista Caatinga, v.25, n.1, p. 45-51, 2012. https://periodicos.ufersa.edu.br/index.php/caatinga/article/ view/2073

DAN, L.G.; DAN, H.A.; BRACCINI, A.L.; ALBRECHT, L.P.; RICCI, T.T.; PICCININ, G.G. Desempenho de sementes de soja tratadas com inseticidas e submetidas a diferentes períodos de armazenamento. Revista Brasileirade Ciências Agrarias, v.6, n.2, p.215-222, 2011. https://doi.org/10.5039/agraria.v6i2a939 
DELOUCHE, J. C. Deterioração de sementes. Seednews, v.6, n.6, p.24-31,2002. https://seednews.com.br/artigos/2018-germinacaodeterioracao-e-vigor-da-semente-edicao-novembro-2002.

FERREIRA, E.B.; CAVALCANTI, P.P.; NOGUEIRA, D.A. ExpDes: An R Package for ANOVA and Experimental Designs. Applied Mathematics, v.5, n.19, p.2952-2958,2014. http://www.scirp.org/journal/doi.aspx?DOI=10.4236/am.2014.519280.

FRANÇA-NETO, J.B.; HENNING, A.A.; YORINORI, J.T. Caracterização dos problemas de fitotoxicidade de plântulas de soja devido ao tratamento de sementes com fungicida Rhodiauram 500 SC, na safra 2000/01. Documentos/Embrapa Soja $n^{\circ} 27$. Londrina: Embrapa Soja, 2000.

FRANÇA-NETO, J.B.; KRZYZANOWSKI, F.; COSTA, N.P. Metodologia do teste de tetrazólio em sementes de soja. Documentos/Embrapa Soja, $n^{\circ}$ 406. Londrina: Embrapa Soja, 2018.

HENNING, A.A. A ferrugem pode ser controlada pelo tratamento de sementes. Documentos/Reunião de pesquisa de soja, na região central do Brasil no 28. Uberaba: Ata., 2006.

HENNING, A.A. Patologia e tratamento de sementes: noções gerais. Documentos / Embrapa Soja, n² 264. Londrina: Embrapa Soja, 2005.

LORENZETTI, E.R.; RUTZEN, E.R.; NUNES, J.; CREPALLI, M.S.; LIMA, P.H.P.; MALFATO, R.A.; OLIVEIRA, W.C. Influência de inseticidas sobre a germinação e vigor de sementes de milho após armazenamento. Cultivando o Saber, v.7, n.1, p.14-23, 2014.

MARCOS-FILHO, J. Teste de envelhecimento acelerado. In: KRZYZANOWSKI, F.C.; VIEIRA, R.D.; FRANÇA-NETO, J.B.; MARCOS-FILHO, J. (Ed.). Vigor de sementes: conceitos e testes. ABRATES, 2020. p.197-204.

MARCOS-FILHO, J. Fisiologia de sementes de plantas cultivadas. $2^{\circ}$ Ed. Londrina: ABRATES, 2015. 659 p.

MARCOS-FILHO, J.; NOVEMBRE, A.D.C.; CHAMMA, H.M.C.P. Tamanho da semente e o teste de envelhecimento acelerado para soja. Scientia Agricola, v.57, n.3, p.473-482, 2000. https://doi.org/10.1590/S0103-90162000000300016

MUNKVOLD, G.; SWEETS, L.; WINTERSTEEN, W. Iowa commercial pesticide applicator manual - Categoria. lowa State University, v.1, p.9, 2006. https://extension.missouri.edu/publications/m92.

PEREIRA, C.E.; OLIVEIRA, J.A.; GUIMAR̈ES, R.M.; VIEIRA, A.R.; EVANGELISTA, J. R. E.; OLIVEIRA, G. E. Tratamento fungicida e peliculização de sementes de soja submetidas ao armazenamento. Ciência e Agrotecnologia, v.35, n.1, p.158-164, 2011. https:// doi.org/10.1590/S1413-70542011000100020

PEREIRA, L.C.; GARCIA, M.M.; BRACCINI, A.L.; FERRI, G.C.; SUZUKAWA, A.K.; MARTELI, D.C.V.; MATERA, T.C.; PEREIRA, R.C.; CORREIA, L.V. Physiological potential of soybean seeds over storage after industrial treatment. Journal of Seed Science, v.40, n.3, p.272-280, 2018. https://doi.org/10.1590/2317-1545v40n3185104

R CORE TEAM. A language and environment for statistical computing. 2018. https://www.r-project.org/

TEKRONY, D.M. Precision is an essential component in seed vigour testing. Seed Science and Technology, v.31, n.2, p.435-447, 2003. https://doi.org/10.15258/sst.2003.31.2.20

VECCHIATO, M.H.; KOHARA, E.Y.; MENTEN, J.O. M. Efeito do armazenamento em sementes de feijão tratadas com fungicidas. Fitopatologia Brasileira, v.1, n.2, p.204-208, 1994. use, distribution, and reproduction in any medium, provided the original work is properly cited. 